\title{
Factors that determine the motivation to change alcohol consumption in cardiovascular patients: an exploratory study
}

\author{
Myrna Keurhorst ${ }^{*}$, Angelien Sieben, Gerard Schippers, Miranda Laurant, Bas Bredie
}

From International Network on Brief Interventions for Alcohol and Other Drugs (INEBRIA) Meeting 2013

Rome, Italy. 18-20 September 2013

\section{Background}

Cardiovascular diseases (CVDs) remain the primary cause of mortality worldwide. Harmful use of alcohol is an important causative lifestyle risk factor for CVD. Motivation to change one's lifestyle is an important determinant of actually changing lifestyle. However, little is known about factors that could be used to modify an individual's motivation to change.

\section{Aim}

To examine in patients with manifest CVD which factors determine motivation to change alcohol consumption.

\section{Participants}

2037 subsequent patients in the departments of General Internal Medicine, Cardiology, Neurology, and Vascular Surgery, most of whom had had a recent CVD event, participated in the study.

\section{Methods}

They completed a cardiovascular risk assessment, including a computerized self-report lifestyle questionnaire and motivation to change behavior. In this presentation we focus, however, on alcohol use.

\section{Results}

On a scale from 1 (not willing to change) to 5 (definitely willing to change), patients scored 1.68 willingness to change their alcohol consumption. Being female, older and a smoker were positively associated with the motivation to change. The relationship between participants' age and their motivation to reduce their alcohol consumption

\footnotetext{
* Correspondence: m.keurhorst@iq.umcn.nl

Radboud University Nijmegen Medical Center, Scientific Institute for Quality of Healthcare, Nijmegen, NL
}

(c) 2013 Keurhorst et al; licensee BioMed Central Ltd. This is an Open Access article distributed under the terms of the Creative Commons Attribution License (http://creativecommons.org/licenses/by/2.0), which permits unrestricted use, distribution, and reproduction in any medium, provided the original work is properly cited.
Cite this article as: Keurhorst et al: Factors that determine the

motivation to change alcohol consumption in cardiovascular patients: an exploratory study. Addiction Science \& Clinical Practice 2013 8(Suppl 1):A39.
Submit your next manuscript to BioMed Central and take full advantage of:

- Convenient online submission

- Thorough peer review

- No space constraints or color figure charges

- Immediate publication on acceptance

- Inclusion in PubMed, CAS, Scopus and Google Scholar

- Research which is freely available for redistribution

Submit your manuscript at www.biomedcentral.com/submit
( Biomed Central 